\title{
Propolis Inhibits UVA-Induced Apoptosis of Human Keratinocyte HaCaT Cells by Scavenging ROS
}

\author{
Han Bit Kim and Byung Sun Yoo \\ Department of Life Science, Kyonggi University, Suwon, Korea
}

(Received July 3, 2016; Revised July 11, 2016; Accepted July 26, 2016)

\begin{abstract}
Propolis is a resinous material collected by honeybees from several plant sources. This research aimed at showing its protective effect against UVA-induced apoptosis of human keratinocyte HaCaT cells. Using Hoechst staining, it was demonstrated that propolis $(5$ and $10 \mu \mathrm{g} / \mathrm{mL})$ significantly inhibited the apoptosis of $\mathrm{HaCaT}$ cells induced by UVA-irradiation. Propolis also showed the protective effect against loss of mitochondrial membrane potential induced by UVA-irradiaiton in HaCaT cells. Propolis also inhibited the expression of activated caspase- 3 induced by UVA-irradiation. To investigate the role of ROS in UVAinduced apoptosis and protection by propolis, the generation of ROS was determined in cells. The results showed that the generation of ROS was markedly reduced in cells pretreated with propolis. Consequently, propolis protected human keratinocyte $\mathrm{HaCaT}$ cells against UVA-induced apoptosis, which might be related to the reduction of ROS generation by UVA-irradiation.
\end{abstract}

Key words: Propolis, UVA, Keratinocyte, Apoptosis, ROS

\section{INTRODUCTION}

Ultraviolet (UV) radiation of sunlight elicits a broad range of effects on cells. UV radiation is one of the most important external stimulus that affects skin by inducing immune suppression, cancer, premature skin aging, inflammation and cell death (1). Apoptosis is a regulated physiological form of cell death, which occurs under a variety of physiological and developmental conditions and in response to many cytotoxic agents. UV irradiation has been shown to be a particularly potent inducer of apoptosis. Apoptosis of keratinocytes in the epidermis manifested in form of sunburn cells $(2,3)$. It is well known that UV radiation induces the generation of reactive oxygen species (ROS), such as superoxide anion, hydroxyl radicals and hydrogen peroxide, and also that ROS are the key mediators on many of UV-induced biological effects $(4,5)$. The targets of reactive oxygen species in the skin are lipids, proteins, collagen, and DNA.

Propolis is a resinous substance collected from various

Correspondence to: Byung Sun Yoo, Department of Life Science, College of Natural Sciences, Kyonggi University, Gwanggyosna-ro 154-42, Suwon-si, Gyeonggi-do 16227, Korea

E-mail: yoobs@kgu.ac.kr

This is an Open-Access article distributed under the terms of the Creative Commons Attribution Non-Commercial License (http:// creativecommons.org/licenses/by-nc/3.0) which permits unrestricted non-commercial use, distribution, and reproduction in any medium, provided the original work is properly cited. plant sources by honeybees. It has a long history of being used in folk medicine against inflammation, heart diseases, diabetes and cancer $(6,7)$. It has a variety of biological properties, such as antibacterial $(8,9)$, antiviral $(10)$, anti-inflammatory (11), antioxidant $(12,13)$, immunomodulatory (14), anticancer (15), and radioprotective activities (16,17). Although the chemical composition of propolis is qualitatively and quantitatively variable depending on the source, more than 300 compounds, mainly polyphenols, have been identified as constituents of the propolis. The major polyphenols in propolis are flavonoids, phenolic acids and their esters, phenolic aldehydes $(6,18,19)$. Recently, propolis has been extensively used in food and beverages to improve health and prevent diseases such as inflammation, heart disease, diabetes and cancer.

Because UV-induced cell damage is primarily attributed to the harmful effects of free radicals, molecules with radical scavenging properties are particularly promising as radioprotectors. Radioprotective effects of antioxidant compounds present in propolis are reported (20-23). However, the photoprotective effect of propolis has not been fully investigated. In the present study, we investigated the effects of propolis on UVA-induced apoptosis of human keratinocyte HaCaT cells.

\section{MATERIALS AND METHODS}

Propolis. Crude propolis was collected from the region of Yongin (Gyeonggi, Korea), and kept desiccated in a 
refrigerator $\left(-20^{\circ} \mathrm{C}\right)$ before being processed. Ethanol propolis extract (EEP) was prepared by the following procedure. Briefly, frozen propolis was powdered in a blender, placed in $95 \%$ ethanol solution and incubated at room temperature for 3 months. The ethanol extract was filtered through Whatman No. 2 paper. The filtered ethanol extract was evaporated to dryness, yielding $152 \mathrm{mg} / \mathrm{mL}$.

Cell culture and treatment. Human keratinocyte $\mathrm{HaCaT}$ cells were cultured in RPMI 1640 medium (GIBCO Lab., Grand Island, NY, USA), supplemented with or without $10 \%$ fetal bovine serum and 100 units of penicillin/streptomycin, in a $\mathrm{CO}_{2}$ incubator at $37^{\circ} \mathrm{C}$. HaCaT cells were cultured in 6 well and 24 well plates (Costar, Cambridge, MA, USA). Propolis solution was directly added to the culture medium.

UVA-irradiation. Human keratinocyte HaCaT cells $\left(2 \times 10^{4}\right.$ cells $\left./ \mathrm{mL}\right)$ were grown in 24 -well plates for $24 \mathrm{hr}$. For UV exposure, the medium was removed from the dish, and then culture medium without FBS was added to the dish. UV irradiation (UVA $4 \mathrm{~J} / \mathrm{cm}^{2}$ ) was supplied by UV cross-linker (Vilber Lourmat, France) equipped with $6 \times$ $8 \mathrm{~W}$ tubes which emits most of their energy with an emission peak at $365 \mathrm{~nm}$ (UVA). After irradiation, cells were incubated in RPMI 1640 medium with 10\% FBS.

Hoechst 33258 staining. Apoptotic nuclear morphology was assessed using Hoechst 33258 staining. Human keratinocyte $\mathrm{HaCaT}$ cells were incubated in 24-well plate at a density of $1 \times 10^{5}$ cells per well for $24 \mathrm{hr}$ before UVA irradiation as described above. Following $6 \mathrm{hr}$ incubation after UVA irradiation, cells were washed twice with icecold PBS and fixed for $10 \mathrm{~min}$ in $4 \%$ paraformaldehyde, and then stained with $10 \mu \mathrm{g} / \mathrm{mL}$ Hoechst 33258 for $20 \mathrm{~min}$. After washing with PBS, cells were observed under the inverted fluorescence microscope (BX70, Olympus, Tokyo, Japan) to identify cells undergoing apoptosis.

Measurement of mitochondrial membrane potential.

The mitochondrial membrane potential of cells was measured with the Rhodamine 123 staining as previously described (24). Briefly, cells were incubated in 24-well plate at a density of $1 \times 10^{5}$ cells per well for $24 \mathrm{hr}$ before UVA irradiation. Following $6 \mathrm{hr}$ incubation after UVA irradiation, the cells were stained $10 \mu \mathrm{M}$ Rhodamine 123 (SigmaAldrich, St. Louis, MO, USA) for $30 \mathrm{~min}$. The fluorescence images were obtained under fluorescence microscopy (BX70, Olympus, Tokyo, Japan).

Western blot of caspase-3. Cells were collected by centrifugation and washed with ice-cold PBS. The washed cell pellets were then resuspended in an extraction lysis buffer (50 mM HEPES pH 7.5, $150 \mathrm{mM} \mathrm{NaCl}, 10 \%$ glycerol, $1 \%$ Triton X-100, $1.5 \mathrm{mM} \mathrm{MgCl}_{2}, 5 \mathrm{mM}$ EDTA) contain- ing protease inhibitor cocktail (Bio Basic Inc., Ontario, Canada) at $4^{\circ} \mathrm{C}$ for $30 \mathrm{~min}$. Total proteins were obtained from centrifugation at $13,000 \times \mathrm{g}$ for $30 \mathrm{~min}$ at $4^{\circ} \mathrm{C}$. The protein concentrations were determined by Bradfordassay. For Western blotting, appropriate amounts of cell lysates $(\sim 30 \mu \mathrm{g})$ were separated at 10\% SDS-polyacrylamide gel electrophoresis and electro-trasnferred onto PVDF membrane (Bio-Rad Laboratories Inc., Hercules, CA, USA). After blocking the membranes with 5\% skim milk powder in TBS-Tween at room temperature for $1.5 \mathrm{hr}$, the membranes were incubated with primary antibodies against cleaved caspase-3 (Cell Signaling Technology, Beverly, MA, USA, $1 / 1000$ ) for $1 \mathrm{hr}$, followed by incubation with horseradish peroxidase-conjugated secondary antibody (Zymed, San Francisco, CA, USA). After washes three times with TBSTween, immunoreactive bands were visualized using standard ECL detection reagents (LAbFrontier, Seoul, Korea).

Measurement of intracellular ROS generation. Production of intracellular ROS was detected by staining cells with the fluorescent probe 2',7'-dichlorofluorescein diacetate (DCFH-DA; Molecular Probes, Leiden, Netherlands) as described previously (25). This dye is a stable compound that readily diffuses into cells and is hydrolyzed by intracellular esterase to yield $\mathrm{DCFH}$, which is trapped within cells. HaCaT cells were incubated in 24-well plate at a density of $1 \times 10^{5}$ cells per well in the presence and absence of propolis for $24 \mathrm{hr}$ before UVA irradiation. Following $6 \mathrm{hr}$ incubation after UVA irradiation, the cells were incubated with $10 \mu \mathrm{M}$ DCF-DA at $37^{\circ} \mathrm{C}$ for $30 \mathrm{~min}$, and then washed twice with PBS. The fluorescence images were obtained under fluorescence microscopy (BX-50, Olympus; 485-nm excitation and 535-nm emission).

Statistical analysis. All experiments were performed with each assay in triplicate. Statistical evaluation was performed using Student's $t$-test or one-way analysis of variance followed by the Fisher's least significant difference procedure as appropriate. A value of $p<0.05$ was considered significant. All data are expressed as mean \pm S.D.

\section{RESULTS}

Content of total flavonoid compounds in ethanol extract of propolis. The composition of propolis depends on the vegetation of the collection area. The estimation of total flavonoid contents in the ethanol extracts of Korean propolis was done by colorimetric method. We used quercetin as a standard compound. The total flavonoid content of our propolis sample was $10.31 \pm 0.84 \mathrm{~g}$ per $100 \mathrm{~g}$ ethanol extract.

Effect of propolis against UVA-induced apoptosis of HaCaT cells. Nucleus condensation is one of the characteristics in the cells undergoing apoptosis. To investigate 
(A)

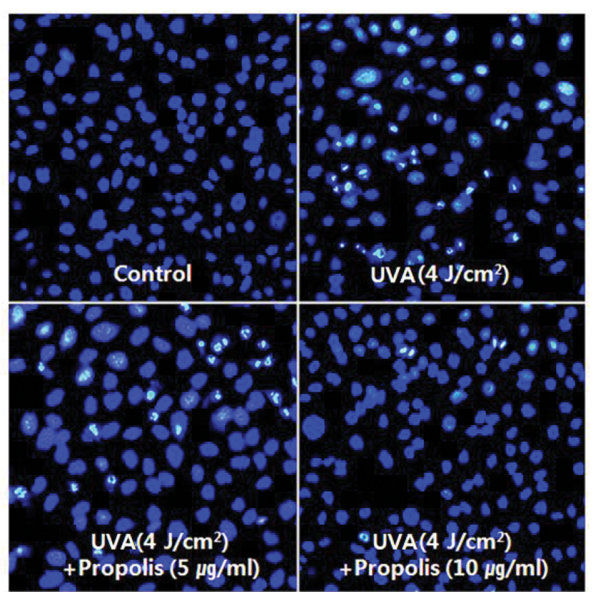

(B)

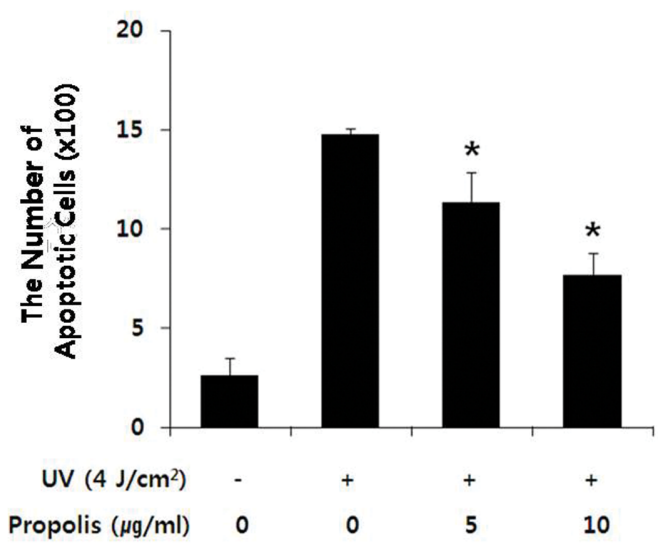

Fig. 1. Propolis inhibited UVA-induced apoptosis in HaCaT cells. Cells were pretreated with or without propolis (5 and $10 \mu \mathrm{g} / \mathrm{mL})$ for $1 \mathrm{hr}$ and then irradiated with UVA $\left(4 \mathrm{~J} / \mathrm{cm}^{2}\right)$. After incubation for $6 \mathrm{hr}$, cells were stained with Hoechst 33258. (A) Representative morphology visualized under a fluorescence microscope (BX70, Olympus, Tokyo, Japan). Cells with brightly fluorescent and fragmented nuclei were apoptotic. (B) Quantitative analysis of the percentage of apoptotic cells. The percentage of apoptotic cells $=$ The numbers of apoptotic cells/(The numbers of apoptotic cells + The numbers of viable cells). ${ }^{*} P<0.05$ when compared to control group.

whether the changes in cellular morphology after UVA-irradiation were due to apoptosis, nuclear morphology was evaluated by fluorescence microscopy using Hoechst 33258 staining. As shown in Fig. 1A, Clear image of the negative control showed rare apoptotic cells, but typical fluorescence photographs revealed shrunken nuclei and chromatic condensation in the HaCaT cells irradiated with UVA (4 J/ $\mathrm{cm}^{2}$ ). However, pretreatment with 5 and $10 \mu \mathrm{g} / \mathrm{mL}$ of propolis for $1 \mathrm{hr}$ before UVA-irradiation resulted in protection against UVA-induced apoptosis of HaCaT cells (Fig. 1B).

\section{Mitochondrial membrane potential change induced} by UVA-irradiation in HaCaT. Mitochondria are thought to be the controller of apoptosis. In particularly, mitochondrial membrane potential (MMP) is a key parameter to assess cellular energy metabolism. The loss of MMP, associated with the opening of large pores in the mitochondrial membranes, is a very important event in apoptosis (26). To investigate whether propolis modulates the MMP change upon irradiation of HaCaT cells to UVA, we determined the change of MMP by intensity of fluorescence emitting from a lipophilic cation dye, rhodamine 123 , which is widely used as a flow cytometric probe for MMP. The dye distributes according to the negative membrane potential across the mitochondrial inner membrane (27). Loss of potential will result in loss of the dye and, therefore, the fluorescence intensity. As shown in Fig. 2, Loss of mitochondrial membrane potential was observed in cells irradiated by UVA $\left(4 \mathrm{~J} / \mathrm{cm}^{2}\right)$. However, pretreatment with 5 and $10 \mu \mathrm{g} / \mathrm{mL}$ of propolis $1 \mathrm{hr}$ before UVA-irradiation resulted in protection against loss of mitochondrial membrane potential of $\mathrm{HaCaT}$ cells. This suggests that propolis treatment can prevent

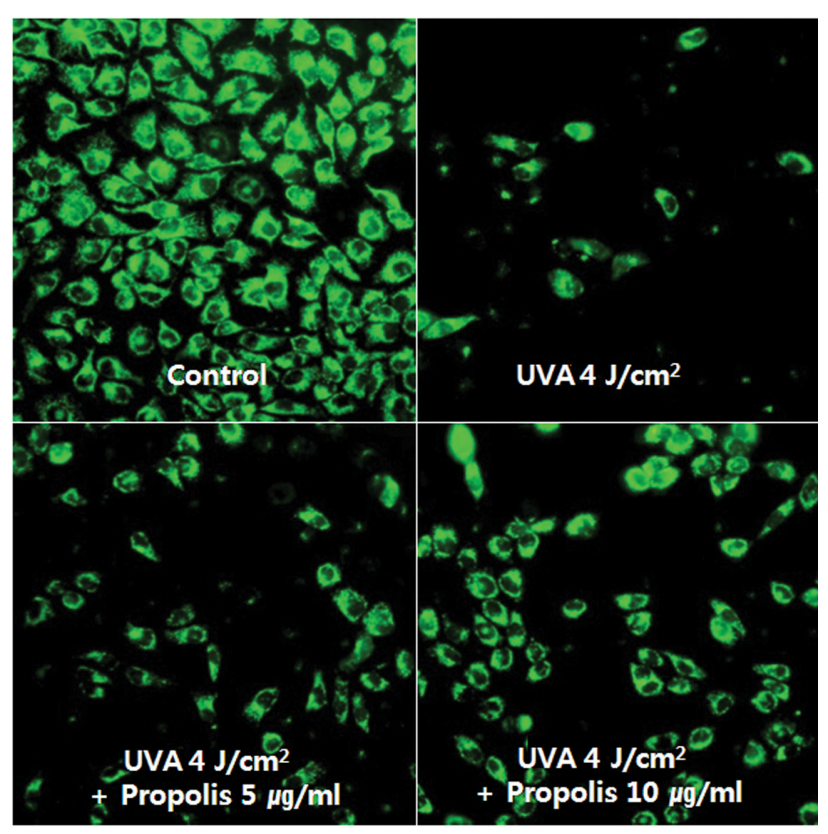

Fig. 2. Propolis recovered the loss of UVA-induced mitochondrial membrane potential in $\mathrm{HaCaT}$ cells. $\mathrm{HaCaT}$ cells were pretreated with or without propolis $(5$ and $10 \mu \mathrm{g} / \mathrm{mL}$ ) for $1 \mathrm{hr}$ and then irradiated with UVA $\left(4 \mathrm{~J} / \mathrm{cm}^{2}\right)$ for $6 \mathrm{hr}$. Mitochondrial membrane potential was evaluated using Rhodamine 123 staining. The change of MMP were imaged on fluorescence microscope $(\times 200)$.

mitochondrial dysfunction of UVA-irradiated $\mathrm{HaCaT}$ cells.

Caspase-3 activation in UVA-irradiated HaCaT cells. Caspase activation plays a key role in the process of apop- 


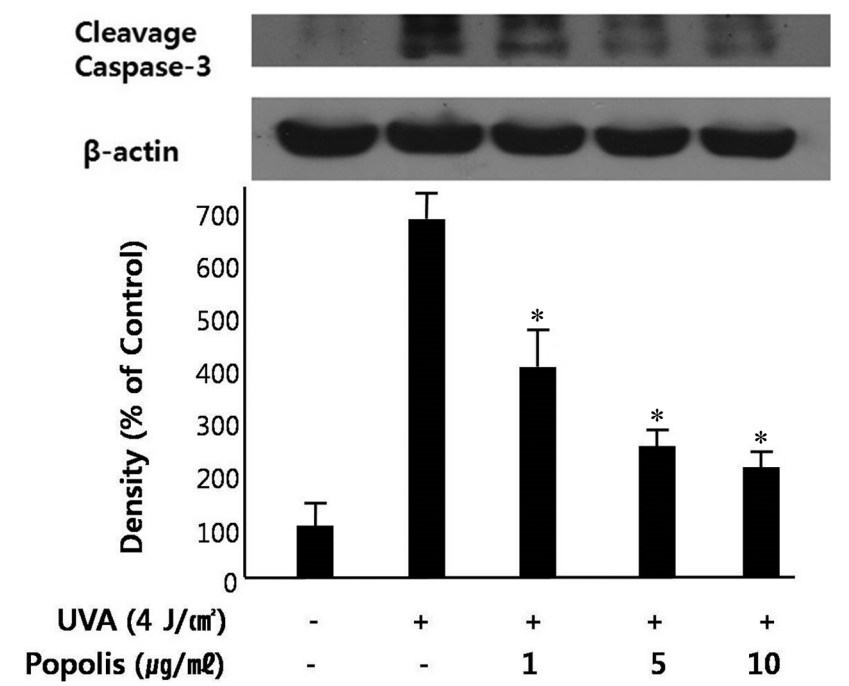

Fig. 3. Effect of propolis on UVA-induced caspase-3 activation in $\mathrm{HaCaT}$ cells. $\mathrm{HaCaT}$ cells were pretreated with or without propolis $(1 \sim 10 \mu \mathrm{g} / \mathrm{mL})$ for $1 \mathrm{hr}$ and then irradiated with UVA $\left(4 \mathrm{~J} / \mathrm{cm}^{2}\right)$. Cells were harvested by centrifugation and protein was extracted. The extracts were analyzed for Western blot analysis of cleaved caspase-3 expression level. Densitometric analysis was performed to determine the intensity of cleaved caspase- 3 bands. Values are normalized to $\beta$-actin band and expressed as the percentage of control group. Data are mean \pm standard error of three independent experiments. ${ }^{*} P<0.05$ when compared to control group. tosis. In particular, caspase- 3 is activated during early apoptosis, and its active form is considered to be an excellent marker of cells undergoing apoptosis. Caspase- 3 is constitutively expressed as proenzyme. Upon stimulation, procaspase3 is cleaved into a active form. The processing of procaspase- 3 into the active cleaved caspase- 3 can be followed by Western blotting, where the appearance of cleaved caspase3 band is indicative of caspase- 3 activation. As shown in Fig. 3, Western blot analysis demonstrated that UVA-irradiation induced increased expression of cleaved caspage- 3 . Treatment of HaCaT cells with propolis $(1 \sim 10 \mu \mathrm{g} / \mathrm{mL}) 1 \mathrm{hr}$ prior to UVA-irradiation inhibited the activation of caspase3 , suggesting that propolis could protect UVA-induced apoptosis of $\mathrm{HaCaT}$ cells.

ROS production in UVA-irradiated HaCaT cells. The generation of intracellular ROS may be related to the induction of apoptosis in various cell types (28-30). And also, it is well known that ROS may play a role in triggering apoptosis of UVA-irradiated cells (31-33). To investigate whether propolis prevents UVA-induced apoptosis of HaCaT cells by decreasing ROS formation, the level of intracellular ROS was evaluated by fluorescence microscopy with the oxidant-sensitive probe DCFH-DA (34). This dye is a stable compound that readily diffuses into cells and is hydrolyzed by intracellular esterase to yield DCFH, which is trapped within cells. ROS produced by cells oxidizes

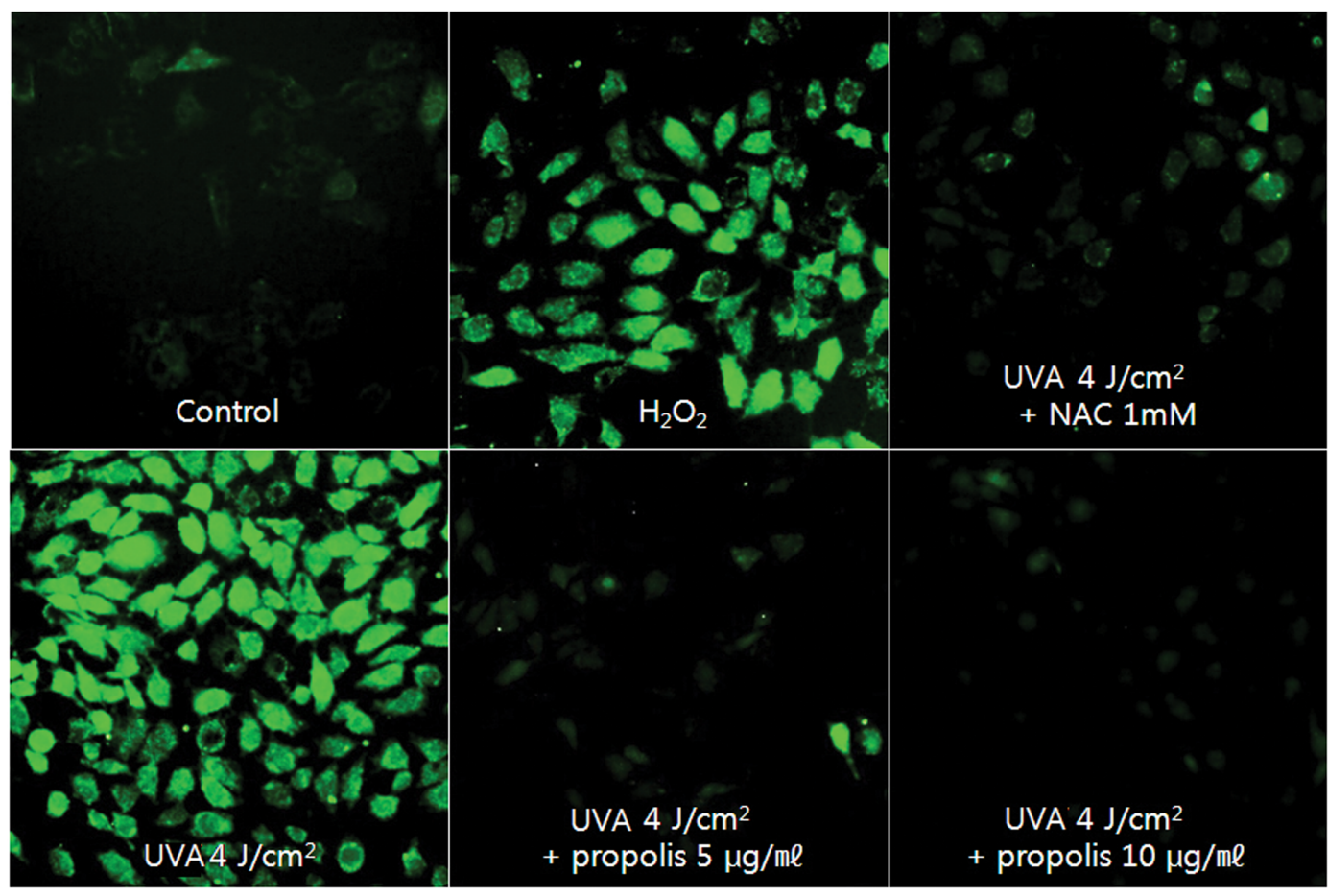

Fig. 4. Effect of propolis on UVA-induced ROS generation in HaCaT cells. HaCaT cells were pretreated with or without propolis $(5$ and $10 \mu \mathrm{g} / \mathrm{mL}$ ) for $1 \mathrm{hr}$ and then irradiated with UVA $\left(4 \mathrm{~J} / \mathrm{cm}^{2}\right)$. After incubation for $6 \mathrm{hr}$, cells were stained with DCFH-DA for $30 \mathrm{~min}$ and washed with PBS. The intracellular levels of ROS were imaged on fluorescence microscope. 
DCFH to the highly fluorescent compound 2',7'-dichlorofluorescein (DCF). Thus, the fluorescence intensity is proportional to the amount of ROS generated by the cells. As shown in Fig. 4, an increase in fluorescence was observed in cells irradiated by UVA $\left(4 \mathrm{~J} / \mathrm{cm}^{2}\right)$, which was reduced in the presence of propolis in a concentration dependent manner (Fig. 4). These results demonstrated that propolis reduced ROS generation in UVA-irradiated $\mathrm{HaCaT}$ cells as free radical scavenger.

\section{DISCUSSION}

It is well known that ROS are the key mediators on many of UV-induced biological effects, including apoptosis $(4,5,35)$. And, many reports have also demonstrated that flavonoids (including flavones, flavonols, flavanones and dihydroflavonols) and various phenolics (mainly substituted cinnamic acids and their esters) are the most important active constituents in propolis possessing potent antioxidant activities and thereby have been capable of scavenging free radicals (36-39). We found that Korean propolis (5 and $10 \mu \mathrm{g} / \mathrm{mL}$ ) reduced ROS production by UVA-irradiation in human keratinocyte $\mathrm{HaCaT}$ cells. Elevated ROS level by UVA irradiation can also decrease mitochondrial membrane potential, leading to the release of cytochrome $\mathrm{C}$ and apoptosis-inducing factors. We found that low concentration of propolis ( 5 and $10 \mu \mathrm{g} / \mathrm{mL}$ ) could recover MMP level in UVA-irradiated $\mathrm{HaCa} \mathrm{T}$ cells.

It has been demonstrated that propolis and some of its active substances have anti carcinogenic and antitumor effect both in vitro and in vivo tumor models (40-43). Propolis and its phenolic compounds have been demonstrated to induce inhibition of growth and apoptotic cell death in human melanoma A2058 cells, human breast cancer MCF7 cells, human neuroblastoma IMR-32 cells, rat glioma C6 cells, and human leukemia HL-60 cells (44), as well as human leukemia U937 cells (15) and four human colon carcinoma cell lines (45), among others. One of the mechanisms of the antitumor activity of propolis has been suggested to be the induction of apoptosis through caspase-dependent or independent pathways (46-48). Because of its cytotoxic effects on tumor cells, the potential use of propolis in treatment of cancer patients has been expected. Although propolis and its active compounds could induce apoptosis in several cancer cell lines, we, however, showed that Korean propolis $(5$ and $10 \mu \mathrm{g} / \mathrm{mL}$ ) protected human keratinocyte $\mathrm{HaCaT}$ cells against apoptosis induced by UVA-irradiation. These results were coincident with protective effect of propolis against UVC-irradiation in HaCaT cells (49).

In vitro toxicological studies of Brazilian green propolis have revealed low concentrations with anti-mutagenicity and high concentrations with mutagenicity (50). It means that propolis and its active compounds might have both procytotoxic (higher concentration) and anti-cytotoxic (lower concentration of propolis) effects on various cell types, depending on concentrations of propolis.

\section{ACKNOWLEDGMENTS}

We would like to thank Dr. Sang Bok Kim (ACEL, Canada) for English correction. This work was supported by the Kyonggi University Research Grant 2013.

\section{CONFLICT OF INTEREST}

Authors declare that there are no conflicts of interest.

\section{REFERENCES}

1. Aragane, Y., Kulms, D., Metze, D., Wilkes, G., Pöppelmann, B., Luger, T.A. and Schwarz, T. (1998) UV light induces apoptosis via direct activation of CD95 (Fas/APO- 1) independently of it's ligand CD95L. J. Cell Biol., 140, 171-182.

2. Danno, K. and Horio, T. (1987) Sunburn cell: factors involved in its formation. Photochem. Photobiol., 45, 683-690.

3. Ziegler, A., Jonason, A.S., Leffell, D.J., Simon, J.A., Sharma, H.W., Kimmelman, J., Remington, L., Jacks, T. and Brash, D.E. (1994) Sunburn and p53 in the onset of skin cancer. Nature, 372, 773-776.

4. Fuchs, J. and Packer, L. (1991) Photooxidative Stress in the Skin in Oxidative Stress: Oxidants and Antioxidants (Sies, H. Ed.). Academic Press, London, pp. 559-583.

5. Heck, D.E., Gerecke, D.R., Vetrano, A.M. and Laskin, J.D. (2004) Solar ultraviolet radiation as a trigger of cell signal transduction. Toxicol. Appl. Pharmacol., 195, 288-297.

6. Banskota, A.H., Tezuka, Y. and Kadota, S. (2001) Recent progress in pharmacological research of propolis. Phytother. Res., 15, 561-571.

7. Burdock, G.A. (1998) Review of the biological properties and toxicity of bee propolis (propolis). Food Chem. Toxicol., 36, 347-363.

8. Bankova, V. (2005) Chemical diversity of propolis and the problem of standardization. J. Ethnopharmacol., 100, 114117.

9. Sforcin, J.M., Fernandes, A. Jr., Lopes, C.A., Bankova, V. and Funari, S.R. (2000) Seasonal effect on Brazilian propolis antibacterial activity. J. Ethnopharmacol., 73, 243-249.

10. Kujumgiev, A., Tsvetkova, I., Serkedjieva, Y., Bankova, V., Christov, R. and Popov, S. (1999) Antibacterial, antifungal and antiviral activity of propolis of different geographic origin. J. Ethnopharmacol., 64, 235-240.

11. Ledon, N., Casaco, A., Gonzalez, R., Merino, N., Gonzalez, A. and Tolon, Z. (1997) Antipsoriatic, anti-inflammatory, and analgesic effects of an extract of red propolis. Zhongguo Yao Li Xue Bao, 18, 274-276.

12. Chen, C.N., Wu, C.L., Shy, H.S. and Lin, J.K. (2003) Cytotoxic prenylflavanones from Taiwanese propolis. J. Nat. Prod., 66, 503-506.

13. Heim, K.E., Tagliaferro, A.R. and Bobilya, A.R. (2002) Flavonoid antioxidants: chemistry, metabolism and structure activity relationships. J. Nutr. Biochem., 13, 572-584.

14. Orsolic, N. and Basic, I. (2003) Immunomodulation by water- 
soluble derivative of propolis: a factor of antitumor reactivity. J. Ethnopharmacol., 84, 265-273.

15. Aso, K., Kanno, S., Tadano, T., Satoh, S. and Ishikawa, M. (2004) Inhibitory effect of propolis on the growth of human leukemia U937. Biol. Pharm. Bull., 27, 727-730.

16. Liu, G.A. and Zheng, R.L. (2002) Protection against damaged DNA in the single cell by polyphenols. Pharmazie., 57, 852854.

17. Orsolic, N., Benkovic, V., Horvat-Knezevic, A., Kopjar, N., Kosalec, I., Bakmaz, M., Mihaljevic, Z., Bendelja, K. and Basic, I. (2007) Assessment by survival analysis of the radioprotective properties of propolis and its polyphenolic compounds. Biol. Pharm. Bull., 30, 946-951.

18. Castaldo, S. and Capasso, F. (2002) Propolis, an old remedy used in modern medicine. Fitoterapia, 73 Suppl 1, S1-S6.

19. Simões, L.M., Gregório, L.E., Da Silva Filho, A.A., De Souza, M.L., Azzolini, A.E., Bastos, J.K. and Lucisano-Vlim, Y.M. (2004) Effect of Brazilian green propolis on the production of reactive oxygen species by stimulated neutrophils. $J$. Ethnopharmacol., 94, 59-65.

20. Uma Devi, P., Ganasoundari, A., Rao, B.S. and Srinivasan, K.K. (1999) In vivo radioprotection by ocimum flavonoids: survival of mice. Radiat. Res., 151, 74-78.

21. Arora, R., Chawla, R., Puri, S.C., Sagar, R., Singh, S., Kumar, R., Sharma, A.K., Prasad, J., Singh, S., Kaur, G., Chaudhary, P., Qazi, G.N. and Sharma, R.K. (2005) Radioprotective and antioxidant properties of low-altitude Podophyllum hexandrum (LAPH). J. Environ. Pathol. Toxicol. Oncol., 24, 299314.

22. Benkovic, V., Horvat Knezevic, A., Brozovic, G., Knezevic, F., Dikic, D., Bevanda, M., Basic, I. and Orsolic, N. (2007) Enhanced antitumor activity of irinotecan combined with propolis and its polyphenolic compounds on Ehrlich ascites tumor in mice. Biomed. Pharmacother., 61, 292-297.

23. Benkovic, V., Knezevic, A.H., Dikic, D., Lisicic, D., Orsolic, N., Basic, I., Kosalec, I. and Kopjar, N. (2008) Radioprotective effects of propolis and quercetin in c-irradiated mice evaluated by the alkaline comet assay. Phytomedicine, 15, 851858.

24. Lu, Y.Y., Chen, T.S., Wang, X.P., Qu, J.L. and Chen, M. (2010) The JNK inhibitor SP600125 enhances dihydroartemisinin-induced apoptosis by accelerating Bax translocation into mitochondria in human lung adenocarcinoma cells. FEBS Lett., 584, 4019-4026.

25. Shin, D.Y., Kim, G.Y., Li, W., Choi, B.T., Kim, N.D., Kang, H.S. and Choi, Y.H. (2009) Implication of intracellular ROS formation, caspase- 3 activation and Egr-1 induction in platycodon D-induced apoptosis of U937 human leukemia cells. Biomed. Pharmacother., 63, 86-94.

26. Zoratti, M. and Szabò, I. (1995) The mitochondrial permeability transition. Biochim. Biophys. Acta, 1241, 139-176.

27. Vander Heiden, M.G., Chandel, N.S., Williamson, E.K., Schumacker, P.T. and Thompson, C.B. (1997) Bcl-xL regulates the membrane potential and volume homeostasis of mitochondria. Cell, 91, 627-637.

28. Fiers, W., Beyaert, R., Declercq, W. and Vandenabeele, P. (1999) More than one way to die: apoptosis, necrosis and reactive oxygen damage. Oncogene, 18, 7719-7730.

29. Fleury, C., Mignotte, B. and Vayssiere, J.L. (2002) Mitochon- drial reactive oxygen species in cell death signaling. Biochimie, 84, 131-141.

30. Chakraborti, T., Das, S., Mondal, M., Roychoudhury, S. and Chakraborti, S. (1999) Oxidant, mitochondria and calcium: an overview. Cell. Signal., 1, 77-85.

31. Garssen, J., van Steeg, H., de Gruijl, F., de Boer, J., van der Horst, G.T., van Kranen, H., van Loveren, H., van Dijk, M., Fluitman, A., Weeda, G. and Hoeijmakers, J.H. (2000) Transcription coupled and global genome repair differentially influence UV-B-induced acute skin effects and systemic immunosuppression. J. Immunol., 164, 6199-6205.

32. Wenk, J., Brenneisen, P., Meewes, C., Wlaschek, M., Peters, T., Blaudschun, R., Ma, W., Kuhr, L., Schneider, L. and Scharffetter-Kochanek, K. (2001) UV-induced oxidative stress and photoaging. Curr. Probl. Dermatol., 29, 83-94.

33. Kulms, D., Zeise, E., Poppelmann, B. and Schwarz, T. (2002) DNA damage, death receptor activation and reactive oxygen species contribute to ultraviolet radiation induced apoptosis in an essential and independent way. Oncogene, 21, 5844-5851.

34. Chen, Y.C., Lin-Shiau, S.Y. and Lin, J.K. (1998) Involvement of reactive oxygen species and caspase 3 activation in arsenite-induced apoptosis. J. Cell. Physiol., 177, 324-333.

35. Irani, K. (2000) Oxidant signaling in vascular cell growth, death, and survival: a review of the roles of reactive oxygen species in smooth muscle and endothelial cell mitogenic and apoptotic signaling. Circ. Res., 87, 179-183.

36. Moreno, M.I.N., Isla, M.I., Sampietro, A.R. and Vattuone, M.A. (2000) Comparison of the free radical-scavenging activity of propolis from several regions of Argentina. J. Ethnopharmacol., 71,109-114.

37. Kumazawa, S., Hamasaka, T. and Nakayama, T. (2004) Antioxidant activity of propolis of various geographic origins. Food Chem., 84, 329-339.

38. Banskota, A.H., Tezuka, Y., Adnyana, I.K., Ishii, E., Midorikawa, K., Matsushige, K. and Kadota, S. (2001) Hepatoprotective and anti-Helicobacter pylori activities of constituents from Brazilian propolis. Phytomedicine, 8, 16-23.

39. Mohammadzadeh, S., Sharriatpanahi, M., Hamedi, M., Amanzadeh, Y., Ebrahimi, S.E.S. and Ostad, S.N. (2007) Antioxidant power of Iranian propolis extract. Food Chem., 103, 729733.

40. Chiao, C., Carothers, A.M., Grunberger, D., Solomon, G., Preston, A.G. and Barrett, C.J. (1995) Apoptosis and altered redox state induced by caffeic acid phenethyl ester (CAPE) in transformed rat fibroblast cells. Cancer Res., 55, 3576-3583.

41. Rao, C.V., Desai, D., Rivenson, A., Simi, B., Amin, S. and Reddy, S.B. (1995) Chemoprevention of colon carcinogenesis by phenylethyl-3-methylcaffeate. Cancer Res., 55, 2310-2315.

42. Xuan, H., Zhao, J., Miao, J., Li, Y., Chu, Y. and Hu, F. (2011) Effect of Brazilian propolis on human umbilical vein endothelial cell apoptosis. Food Chem. Toxicol., 49, 78-85.

43. Eom, H.S., Lee, E.J., Yoon, B.S. and Yoo, B.S. (2010) Propolis inhibits the proliferation of human leukaemia HL-60 cells by inducing apoptosis through the mitochondrial pathway. Nat. Prod. Res., 24, 375-386.

44. Chen, C.N., Wu, C.L. and Lin, J.K. (2007) Apoptosis of human melanoma cells induced by the novel compounds propolin A and propolin B from Taiwenese propolis. Cancer Lett., 245, 218-231. 
45. Ishihara, M., Naoi, K., Hashita, M., Itoh, Y. and Suzui, M. (2009) Growth inhibitory activity of ethanol extract of Chinese and Brazilian propolis in four human colon carcinoma cell lines. Oncol. Rep., 22, 349-354.

46. Huang, W.J., Huang, C.H., Wu, C.L., Lin, J.K., Chen, Y.W., Lin, C.L., Chuang, S.E., Huang, C.Y. and Chen, C.N. (2007) Propolin G, a prenylflavanone, isolated from Taiwanese propolis, induces caspase-dependent apoptosis in brain cancer cells. J. Agric. Food Chem., 55, 7366-7376.

47. Weng, M.S., Liao, C.H., Chen, C.N., Wu, C.L. and Lin, J.K. (2007) Propolin H. from Taiwanese propolis induces G1 arrest in human lung carcinoma cells. J. Agric. Food Chem., 55, 5289-5298.

48. Sforcin, J.M. (2007) Propolis and the immune system: a review. J. Ethnopharmacol., 113, 1-14.

49. Moon, J.Y., Lee, E.J. and Yoo, B.S. (2012) Propolis Protects Human Keratinocyte HaCaT Cells against UV-induced Apoptosis. Journal of Apiculture, 27, 243-249.

50. Tavares, D.C., Mazzaron Barcelos, G.R., Silva, L.F., Chacon Tonin, C.C. and Bastos, J.K. (2006) Propolis-induced genotoxicity and antigenotoxicity in Chinese hamster ovary cells. Toxicol. In Vitro, 20, 1154-1158. 